\title{
Strategi menulis kreatif dalam pembelajaran daring siswa SMP di Kabupaten Pringsewu tahun 2020
}

\author{
Edi Suyanto', Muhammad Fuad ${ }^{2}$ \\ 1,2 Universitas Lampung \\ Correspondence : edi.suyanto@fkip.unila.ac.id
}

\begin{abstract}
Abstrak
Penelitian ini bertujuan mengidentifikasi dan menganalisis strategi yang digunakan siswa dalam menulis kreatif melalui pembelajaran daring, serta kendala yang dihadapi siswa Kelas VIII SMP di Kabupaten Pringsewu Tahun 2020. Penelitian ini menggunakan metode deskripstif kualitatif, berupa studi kasus. Sumber data berupa proses menulis, termasuk guru dan hasil pembelajaran. Sampel dalam penelitian ini berjumlah 29 siswa, yang ditentukan secara purposif, khususnya siswa yang memiliki kemampuan menulis dengan kategori sepuluh terbaik di sekolahnya. Hasil penelitian menunjukkan keseluruhan siswa dominan menggunakan strategi dalam menulis kreatif, yakni sebanyak $71,55 \%$ dengan kategori baik. Strategi yang dilakukan siswa terkait dengan proses penulisan $(79,31 \%)$, penetapan tujuan ( $48,28 \%)$, pengaturan waktu (58,62\%), dan pemanfaatan bahan (100\%). Untuk produk tulisan ditemukan rerata nilai siswa untuk semua komponen sebesar 77,75 $(83,62 \%)$ dengan kategori baik. Selama proses penulisan ditemukan beberapa kendala, yakni 6,90\% siswa kurang paham dalam hal menetapkan tujuan menulis dan $16,38 \%$ siswa kurang mampu mengelola waktu karena penulisan dilakukan di rumah (terlalu leluasa).
\end{abstract}

Kata Kunci: Strategi menulis kreatif, pembelajaran daring, siswa SMP

\section{Pendahuluan}

Pembelajaran dapat terlaksana apabila direncanakan dan dipersiapkan dengan baik. Pelaksanaannya, guru tidak hanya berprinsip pada apa yang harus diajarkan, tetapi seharusnya berprinsip pada bagaimana cara mengajarkannya (Suyanto, 2005). Ini penting karena pembelajaran identik 
dengan suatu proses yang memerlukan tahapan terencana, jelas, dan terukur (Majid, 2014). Satu hal penting yang tidak dapat diabaikan adalah pemilihan dan penetapan strategi yang akan digunakan dalam pembelajaran. Sebagaimana dijelaskan Itami dalam Kuncoro (2005) strategi merupakan kerangka kerja dari suatu aktivitas yang dapat dijadikan pedoman. Strategi menurut Sanjaya (2006) adalah cara atau teknik yang digunakan guru untuk mencapai tujuan pembelajaran. Lebih lanjut, David (2011) menjelaskan bahwa strategi merupakan alat untuk mencapai tujuan, karena pada dasarnya semua kegiatan secara normatif memiliki tujuan atau sasaran yang jelas. Hal senada juga dijelaskan Kurniawan (2013) bahwa strategi adalah suatu pendekatan yang berkaitan dengan perencanaan, pelaksanaan gagasan, dan aktivitas yang memiliki kurun waktu tertentu. Dengan demikian, jelaslah bahwa strategi pembelajaran sangat urgen bagi terselenggaranya suatu aktivitas belajar, termasuk strategi guru dalam membelajarkan menulis kepada siswa di sekolah .

Menulis dapat dimaknai sebagai suatu kegiatan yang menantang, bahkan acapkali dipandang sulit oleh siswa (Endraswara, 2005). Kesulitan cenderung disebabkan oleh kesalahan guru dalam menentukan strategi (Sanjaya, 2006), yakni lebih mementingkan hasil daripada proses belajar. Yaumi (2012) juga menjelaskan bahwa permasalahan tersebut berakar pada kurangnya pengalaman guru, khususnya dalam hal penggalian kecerdasan siswa melalui perancangan dan strategi pembelajaran yang akan digunakan. Jika hal ini terjadi, dampaknya bagi siswa, antara lain timbul rasa malas, salah konsep, dan hasil menulis siswa kurang memuaskan (Oktoma, 2018). Berbagai alasan pun muncul, antara lain karena penyelesaiannya diperlukan intensitas dan durasi waktu yang cukup sehingga tulisan siswa kurang memuaskan (Kruse, 2013).

Karena prosesnya yang kompleks, Tuan (2010) menjelaskan bahwa kesulitan menulis terjadi karena adanya kerumitan tersendiri. Untuk mengatasi penyebab kesulitan siswa dalam hal menulis, guru hendaknya memberi contoh nyata agar siswa terinspirasi dan nyaman untuk menulis, karena pada dasarnya guru adalah model bagi siswanya. Agar siswa memeroleh kemudahan, guru juga wajib mengarahkan siswanya terkait dengan strategi yang dapat digunakan dalam menulis (Suniyah, 2018). Dengan cara ini tentunya siswa dapat memilih dan menetapkan strategi sehingga dapat mengelola diri sendiri dalam menyelesaikan tulisan dengan mudah dan cepat (Iskandarwasid, 2015). Mohite (2014) pun menegaskan bahwa strategi merupakan salah satu alat pengendali yang berfungsi memberi arah dalam proses penulisan. Strategi yang digunakan penulis dapat dijadikan pedoman yang akan mengarah pada kepercayaan diri untuk menjaga kualitas tulisan sesuai dengan yang diinginkan. Dalam prosesnya harus memerhatikan prinsip belajar (Gintings, 2010) sehingga timbul 
motivasi untuk menulis sebagai bagian dari dirinya. Tosepu (2020) pun menambahkan bahwa penulis harus memiliki wawasan terhadap femonena yang akan diekspresikan secara tertulis sehingga produk tulisan menjadi menarik. Penulis yang nyaman selalu menyadari bahwa dirinya memiliki tujuan untuk menciptakan tulisan, meskipun isi tulisan masih ada kelemahan dan perlu diperbaiki (Bazerman, 1985).

Ada beberapa strategi menulis yang dapat dijadikan pedoman. Sebagaimana dijelaskan Alnufaie, M., \& Grenfell, M., (2012) bahwa menulis kreatif dapat dilakukan dengan menggunakan strategi, seperti menulis bebas, mencontoh penulis terkenal untuk menciptakan ide-ide dan menemukan makna, kelompok atau berpasangan, merevisi tulisan orang lain, penyusunan dan proofreading. Collins (2008) juga menegaskan bahwa menulis yang sebenarnya harus disandarkan pada strategi, termasuk adanya kesadaran mental dalam memilih tema dan teknik menulis untuk mencapai tujuan yang diinginkan. Dengan demikian dapatlah dipahami bahwa strategi menulis merupakan bagian penting yang harus diterapkan, sekaligus akan membantu siswa dalam menulis dengan lebih mudah untuk menciptakan tulisan yang menarik. Untuk itu, proses menulis seyogyanya diarahkan pada pelatihan mental dalam wujud kreativitas kebahasaan. Melalui kemasan tujuan, pembelajarannya seharusnya lebih difokuskan pada proses terlebih dahulu sebelum menitikberatkan pada produk tulisan (Endraswara, 2005; Setiawati, 2016).

Implementasi pembelajaran menulis di sekolah dapat dijadikan tolok ukur yang logis terhadap kualifikasi kebahasaan siswa. Indikator pencapaiannya dapat diidentifikasi dari proses maupun produk tulisan siswa. Dalam hal ini, tulisan yang dimaksud dalam penelitian ini berupa esai formal. Darmawan (2013) menjelaskan bahwa esai formal adalah karangan prosa yang membahas suatu masalah dari sudut pandang pribadi penulisnya. Tujuan penulisan esai menurut Habsi (2020) adalah agar para pembaca esai dapat memercayai sudut pandang permasalahan si penulis yang dituangkan dalam bentuk tulisan. Untuk memperoleh tulisan esai yang menarik, selain tujuan harus pula didukung oleh data dan fakta yang kredibel agar isi tulisan bersifat objektif. Dengan demikian, untuk menulis suatu esai formal, diperlukan kemampuan mengidentifikasi dan menganalisis pengetahuan atau pengalaman terhadap fakta yang akan dikembangkan dalam tulisan. Untuk mengetahui proses menulis dan kualitas tulisan siswa, peneliti bersandar pada teori McLean (2012), yang mencakup strategi proses penulisan, penetapan tujuan, pengaturan waktu, dan pemanfaatan bahan. 


\section{Metode penelitian}

Penelitian ini menggunakan metode deskriptif kualitatif berupa studi kasus. Sumber data berupa proses menulis yang dilaksanakan secara daring, termasuk di dalamnya guru dan dokumen hasil pembelajaran. Teknik yang digunakan dalam pengumpulan data adalah wawancara dengan siswa SMP di Kabupaten Pringsewu yang dilakukan sejak September s.d. Oktober 2020. Data utama berupa pernyataan siswa tentang strategi menulis yang digunakanya, termasuk hasil menulis sebagai data pendukung. Selanjutnya, pengambilan sampel dilakukan secara purposive, yakni sebanyak 29 siswa dengan cara menentukan sepuluh siswa untuk masing-masing sekolah yang tersebar di tiga sekolah, khususnya siswa yang memiliki kemampuan menulis dengan kategori sepuluh terbaik. Karena data yang dianalisis berupa peristiwa dan dokumen, maka teknik yang digunakan untuk menganalisis data adalah interactive model of analysis yang dikembangkan Miles dan Huberman (Sugiyono, 2015).

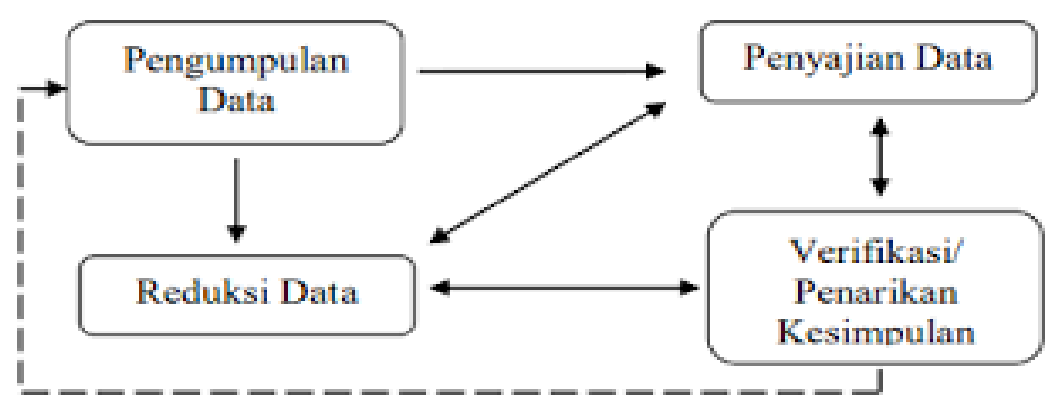

Bagan 1 Model Analisis Interaktif Miles and Huberman (dalam Sugiyono, 2015)

\section{Hasil dan pembahasan}

\section{Hasil}

Berdasarkan hasil wawancara terhadap 29 siswa terkait dengan strategi yang digunakan dalam menulis kreatif diperoleh data (pernyataan, produk tulisan, dan kesalahan dalam penulisan) sebagaimana tertera pada Diagram 1,2 , dan 3 . 


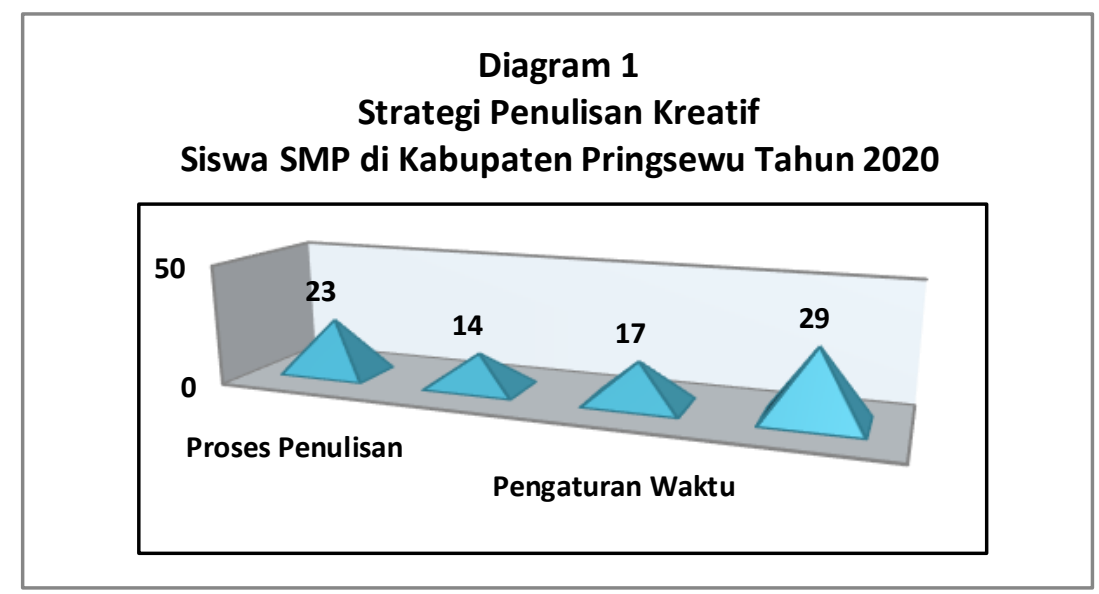

Diagram 1 di atas menggambarkan bahwa seluruh siswa memiliki kecenderungan menggunakan strategi dalam menulis kreatif, yang mencakup seluruh komponen yang dipersyaratkan, yakni sebanyak $71,55 \%$.

Selanjutnya, untuk mengidentifikasi kualitas tulisan siswa, peneliti berpatokan pada tiga aspek, yakni sistematika, isi, penggunaan bahasa, dan penutup.

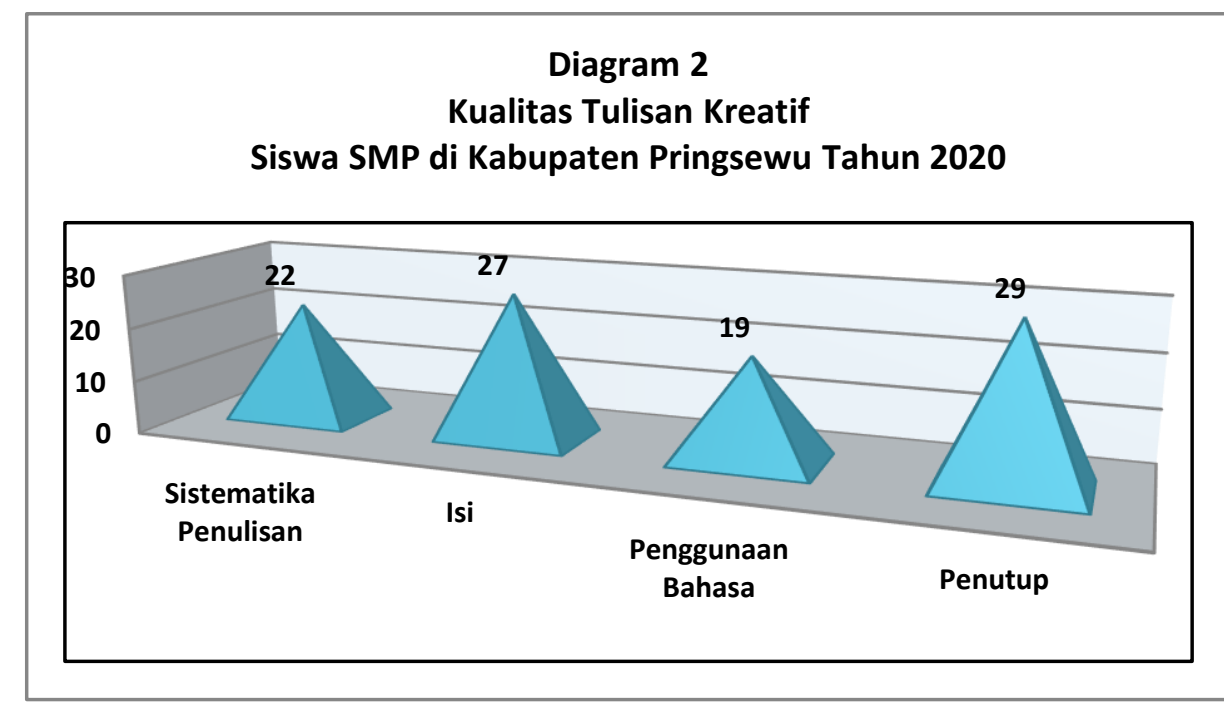

Diagram 2 di atas menggambarkan kualitas tulisan siswa dikategorikan baik karena mencakup semua aspek: sistematika penulisan, isi, penggunaan bahasa, dan penutup. Ini pun tampak jelas dari rerata nilai yang diperoleh 24 siswa sebesar 77,75 (83,62\%) dari 29 siswa.

Disajikan pula kesalahan dalam penulisan sebagai kontrol atas kualitas tulisan siswa. 


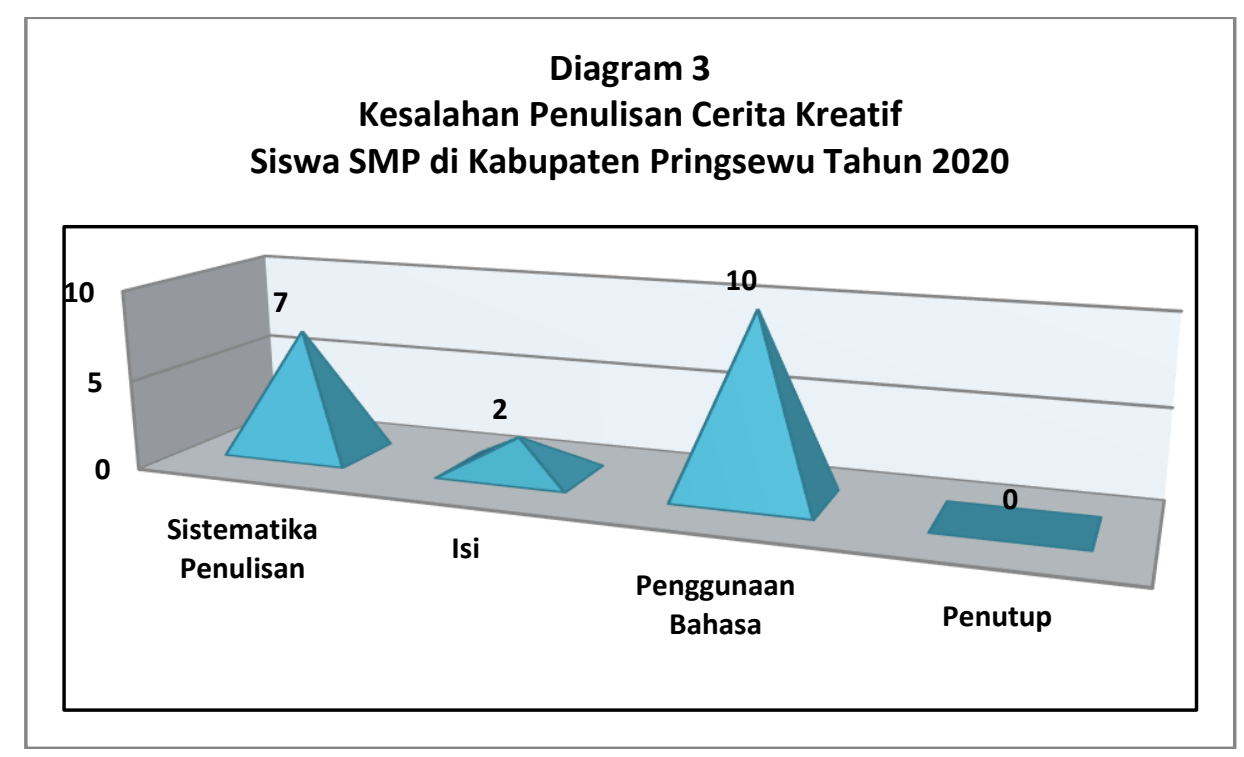

Diagram 3 di atas menggambarkan jumlah dan persentase kesalahan siswa dalam penulisan. Meskipun kualitas tulisan siswa dikategorikan baik, tetapi masih ditemukan kesalahan dalam penulisan sebanyak 10 siswa (16,38\%). Kesalahan penulisan yang cukup dominan, yakni dalam hal penggunaan ejaan dan tanda baca.

\section{Pembahasan}

Pembahasan utama dalam penelitian ini adalah strategi yang digunakan 29 siswa dalam menulis kreatif, berbentuk esai formal.

\section{Strategi penulisan kreatif}

Ikhwal strategi menulis kreatif yang dilakukan siswa, terbagi menjadi empat komponen, yakni proses penulisan, penetapan tujuan, pengaturan waktu, dan pemanfaatan bahan. Implementasinya, masing-masing siswa memiliki kesamaan atau kecenderungan menggunakan strategi dalam menulis kreatif.

\section{Proses penulisan}

Menulis identik dengan menuangkan ide atau gagasan ke dalam bentuk tulis. Untuk dapat menuangkan ide atau gagasan ke dalam bentuk tulis diperlukan pengetahuan dan pengalaman yang memadai sehingga proses penulisan dapat terlaksana dengan baik. Terkait dengan proses penulisan, ditemukan data sebanyak 23 siswa (79,31\%) dengan kategori baik. Jumlah dan persentase data tersebut menggambarkan bahwa proses penulisan sangat dominan. Artinya, untuk menghasilkan sebuah tulisan kreatif diperlukan suatu proses, sebagaimana tercermin dalam Diagram 1. 


\section{Penetapan tujuan}

Agar suatu tulisan dapat bermakna, sudah tentu harus didasari oleh tujuan. Penetapan tujuan sangat penting agar kegiatan menulis dapat terarah. Terkait dengan penetapan tujuan, realisasinya hanya ditemukan data sebanyak 14 siswa $(48,28 \%)$ dengan kategori cukup.

\section{Pengaturan waktu}

Waktu merupakan faktor penting dalam kegiatan menulis. Terkait dengan pengaturan waktu, ditemukan data sebanyak 17 siswa $(58,62 \%)$ dengan kategori cukup. Meskipun dikategorikan cukup, data ini menunjukkan bahwa siswa cenderung tidak memanfaatkan waktu karena tugas menulis dilakukan secara daring dan dikerjakan di rumah (terlalu leluasa) sehingga kurang fokus.

\section{Pemanfaatan sumber}

Sesuai dengan arahan guru bahwa penugasan menulis dikerjakan di rumah dan disarankan memanfaatkan bahan (buku bacaan atau contoh tulisan yang bersumber dari internet, dalam hal ini menggunduh dari aplikasi google). Realisasinya, seluruh siswa memanfaatkan bahan atau sumber pendukung yang relevan. Ada hal krusial yang harus dicermati bahwa adanya keleluasaan memanfaatkan sumber, khususnya google, kecenderungan tulisan siswa terpengaruh, menyadur, bahkan copy paste. Hal ini menjadi catatan penting, khususnya arahan guru kepada siswa agar tidak meng-copy paste hasil tulisan orang laian.

\section{Kualitas dan kesalahan penulisan}

\section{Kualitas tulisan}

Untuk mengetahui relevansi antara penggunaan strategi dan produk tulisan, peneliti melakukan analisis terkait dengan dua hal, yakni kualitas dan kesalahan tulisan. Identifikasi terhadap kualitas dan kesalahan dalam penulisan, peneliti berpatokan pada tiga aspek, yakni sistematika (struktur/organisasi tulisan), isi (kesesuaian dengan tema), penggunaan bahasa (diksi, gramatika, ejaan dan tanda baca), dan penutup (akhir cerita).

\section{Sistematika (organisasi tulisan)}

Sistematika tulisan sangat urgen karena sebuah tulisan akan memiliki pola tersendiri sehingga mudah dibaca dan dipahami isinya. Dikatakan sistematis, jika tulisan memiliki keterkaitan antara bahasa dan informasi yang disajikan dari awal hingga akhir. Kejelasan dan keobjektifan organisasi tulisan ditandai oleh kelugasan makna secara tersurat. Dalam hal sistematika (organisasi tulisan), sebagaimana tertera pada Diagram 2 
ditemukan data sebanyak 22 siswa $(75,86 \%)$ bahwa sistematika tulisan kreatif siswa dikategorikan baik dalam arti siswa memiliki kompetensi menulis kreatif yang komunikatif.

\section{Isi (kesesuaian dengan tema)}

Isi suatu tulisan adalah hal urgen yang akan dipahami pembaca secara simultan, bahkan berkelanjutan. Kemenarikan isi tulisan dapat dimaknai sebagai suatu informasi penting sebagamana diinginkan pembaca. Oleh sebab itu, isi tulisan haruslah relevan atau ada kesesuaian dengan tema yang dikembangkan. Dalam hal isi tulisan, ditemukan 27 siswa (93,10\%) dengan kategori sangat baik yang tercermin dalam produk tulisan siswa.

\section{Penggunaan bahasa (diksi, gramatika, ejaan dan tanda baca)}

Wujud dari suatu tulisan ditandai oleh penggunaan struktur bahasa yang berterima. Keberterimaan yang dimaksud terkait dengan penggunaan diksi (pilihan kata), gramatika, ejaan dan tanda baca secara benar sebagai konkretasi gagasan yang dikembangkan dalam tulisan. Secara lengkap dan lugas, bahasa yang digunakan harus merepresentasikan gagasan yang disajikan sehingga isi atau informasi yang tertuang dapat dipahami dengan mudah. Baik diksi maupun istilah harus terangkai secara gramatis sehingga memiliki informasi yang jelas. Ada kejelasan antara pokok dan sebutan yang teraplikasi langsung dalam organisasi tulisan dalam bentuk penjelasan. Antarkalimat dalam paragraf memiliki kaitan erat (kohesif), dan antarparagraf memiliki koherensi yang mengikat. Penanda dari keberterimaan tulisan pun didukung pula dengan ketepatan penggunaan ejaan dan tanda baca. Dalam hal penggunaan bahasa (diksi, gramatika, ejaan dan tanda baca) dalam tulisan ditemukan data 19 siswa $(65,52 \%)$ dengan kategori baik.

\section{Penutup (akhir cerita)}

Seluruh siswa dapat menutup atau mengakhiri tulisan kreatif. Kemampuan siswa sangat terukur karena tidak ditemukan kelemahan dalam hal mengakhiri tulisan, dengan kata lain dikategorikan sangat baik.

Atas dasar uraian di atas, diperoleh rerata nilai dari seluruh komponen sebesar 77,75 atau 83,62\%. Dengan demikian dapat disimpulkan bahwa kualitas tulisan kreatif siswa dapat dikategorikan baik.

\section{Kesalahan penulisan}

Meskipun kualitas tulisan kreatif siswa dikategorikan baik, tetapi masih ditemukan kesalahan dalam penulisan. Beberapa kesalahan ditemukan, khususnya terkait dengan sistematika penulisan (7 siswa atau 24,14\%), isi 
(2 siswa atau 6,90\%), dan penggunaan bahasa (10 siswa atau 34,48\%) dengan rerata keseluruhan sebesar $16,38 \%$. Dominasi kesalahan penulisan terjadi, khususnya dalam hal penggunaan ejaan dan tanda baca. Dengan demikian, dapat disimpulkan bahwa kesalahan dalam penulisan kreatif siswa dikategorikan cukup.

\section{Simpulan dan saran}

Berdasarkan hasil penelitian dan pembahasan dapat disimpulkan bahwa seluruh siswa dominan menggunakan strategi sesuai dengan yang dipersyaratkan dalam menulis kreatif, yakni sebanyak 29 siswa atau 71,55\% dengan kategori baik. Strategi yang dilakukan siswa tersebut, meliputi (1) proses penulisan sebanyak 23 siswa $(79,31 \%)$, penetapan tujuan sebanyak 14 siswa (48,28\%), pengaturan waktu sebanyak 17 (58,62\%), dan pemanfaatan sumber sebanyak 29 siswa (100\%). Kecenderungan penggunaan startegi ini berdampak signifikan terhadap kualitas produk tulisan siswa. Signifikansi kualitas tulisan tercermin dari rerata nilai yang diperoleh siswa sebesar 77,75 (83,62\%) dengan kategori baik untuk seluruh komponen. Selanjutnya, selama proses penulisan ditemukan beberapa kendala, yakni (1) 51,72\% siswa kurang paham dalam hal menetapkan tujuan menulis esai, dan (2) 41,38\% siswa kurang mampu mengelola waktu karena penulisan dilakukan di rumah (terlalu leluasa). Dalam hal produk tulisan, terdapat 10 siswa atau $34,48 \%$ yang mengalami kesulitan dalam penggunaan bahasa, khususnya penggunaan ejaan dan tanda baca.

Berdasarkan simpulan di atas, ada beberapa hal yang perlu dicermati dan ditindaklanjuti, terutama ikhwal pembelajaran menulis di sekolah. Pertama, guru seyogyanya memberi contoh langsung tentang menulis (jenis maupun bentuknya) agar siswa terinspirasi, nyaman, dan senang menulis. Kedua, adanya keleluasaan mengakses berbagai informasi melalui internet, khususnya aplikasi google, guru harus berupaya dan meyakinkan siswa bahwa bahan/sumber hanya dijadikan rujukan, bukan untuk dijiplak atau disalin karena mengalami kesulitan dalam menulis.

\section{Daftar rujukan}

Alnufaie, M., \& Grenfell, M. (2012). EFL students' writing stratefies in Saudi Arabian ESP writing classes: Perspectives on learning strategies in self-access language learning. Studies in Self-Access Learning Journal, 3(4), 407-422. Retrieved from http://sisaljournal.org, on January $13^{\text {th }}, 2017$.

Ariyanto. (2015). Menulis kreatif. e-journal (2011), diakses dari $h t t p: / / a-$ journo. blogspot.com pada tanggal o7 April 2021, pukul 08.21 WIB 
Bazerman, C. (1985). The informed writer using sources in the diciplines (2nd ed.). Boston: Houghton Mifflin Company.

Collins, J. L. (2008). Writing strategies. Buffalo: New York. Retrieved from http://gse.buffalo.edu/org/writingstrategies/, on January 22nd, 2017.

David, Fred R. (2011). Strategic management manajemen strategi konsep. Jakarta: Salemba Empat.

Endraswara, S. (2005). Metode dan teori pengajaran sastra berwawasan kurikulum berbasis kompetensi. Yogyakarta: Buana Pustaka.

Gintings, Abdorrakhman. (2010). Esensi praktis: Belajar dan pembelajaran. Bandung: Humaniora.

Habsi. (2020). Pengertian, struktur, dan, contoh esai yang patut kamu pahami. Quipper Blog.

http://id.wikipedia.org/wiki/Esai,http://www.pemustaka.com/pengertian -esai-dan-ciri-cirinya.html. Darmawan, Adi. 2013. Pengertian Esai dan Ciri-Cirinya.

https://yusrintosepu.wixsite.com/yoes/post/membingkai-disrupsiperadaban-dengan-menulis. Yusrin Ahmad Tosepu. 2020. Membingkai Disrupsi dengan Menulis.

Iskandarwasid dan Sunendar, Dadang. (2015). Strategi pembelajaran bahasa. Bandung: PT Remaja Rosdakarya.

Kuncoro, Mudrajad. 2005. Strategi bagaimana meraih keunggulan kompetitif. Jakarta: Erlangga.

Kurniawan. 2013. Pengaruh kompetensi pedagogik, dan kompetensi profesional guru. Universitas Pendidikan Indonesia. Pustaka Belajar.

Kruse, O. 2013. Perspectives on academic writing in European higher education: Genres, practices, and competences, Revista de Docencia Universitaria Vol.11 (1) Enero-Abril 2013, 37-58.

Majid, Abdul. 2014. Strategi pembelajaran. Bandung: PT Remaja Rosdakarya.

McLean, S. (2012). Successful writing. Creative Cummons (licensed). Retrieved February 2, 2017, from: 2012books.lardbucket.org/books/successful-writing/

Mohite, M. (2014). An investigation into the English language writing strategies used by EFL secondary school learners (Dissertation, London Metropolitan University, 2014). Retrieved January 5, 2017 from

https://englishagenda.britishcouncil.org/sites/default/files/filefiel $\underline{\mathrm{d} \text { paths/an investigation into the english language writing } \mathrm{s}}$ trategies v2.pdf

Oktoma, Erwin. 2018. Strategi menulis yang digunakan oleh mahasiswa dalam esai argumentatif. Fon; Jurnal Pendidikan Bahasa dan Sastra Indonesia, Volume 12 Nomor 1 Tahun 2018, ISSN Elektronik: 2614-7718|39 ISSN Cetak: 2086-0609.

Putra, Listya Buana, Sumarwati, dan Anindyarini, Atikah. 2016. Implementasi kurikulum 2013 pada pembelajaran menulis teks cerita ulang biografi: Studi kasus di sma negeri 1 Surakarta. Surakarta: Universitas Sebelas Maret. 
Sanjaya, Wina. 2006. Strategi pembelajaran berorientasi standar proses pendidikan. Jakarta: Kencana Prenada Media.

Setiawati, Ika. 2016. Strategi meningkatkan kemampuan menulis karangan kreatif pada siswa kelas 4 dan 5: Studi multikasus di min Rejotangan dan sdn 1 Rejotangan Tulungagung. Blitar: STIT Al-Muslihun

Sugiyono. 2015. Metode penelitian kombinasi (mix methods). Bandung: Alfabeta.

Sukrinto. 2008. Membelajarkan menulis. e-journal, diakses dari http//staffuin.ac. id. pada tanggal 5 April 2021.

Suniyah, Rohmadi, M. dan Tri Sulistiyo, Edy. 2018. Implementasi strategi pembelajaran menulis berbasis multiple intelligences. Surakarta: Universitas Sebelas Maret.

Suyanto, Edi 2005. Strategi menulis berdasarkan permainan tematik untuk siswa sekolah dasar. Bandung: Universitas Indonesia.

Tuan, L. T. 2010. Enhancing efl learners'writing skill via Journal Writing, English Language Teaching Vol. 3, No. 3; September 2010, pp. 8188.

Wati, Riana. 2007. Mengasah kreativitas menulis, upaya membangun budaya bangsa. Jakarta: Pusat Bahasa.

Yaumi, Muhammad. 2012. Pembelajaran berbasis multiple intelligences. Jakarta: Dian Rakyat. 